\title{
Polar localization of the replication origin and terminus in Escherichia coli nucleoids during chromosome partitioning
}

\author{
Hironori Niki ${ }^{\mathbf{1}}$ and Sota Hiraga \\ Department of Molecular Cell Biology, Institute of Molecular Embryology and Genetics, Kumamoto University School \\ of Medicine, Kumamoto 862-0976, Japan

\begin{abstract}
We show the intracellular localization of the Escherichia coli replication origin (oriC) and chromosome terminus during the cell division cycle by FISH. In newbom cells, oriC is localized at the old-pole-proximal nucleoid border and the terminus at the new-pole-proximal nucleoid border. One copy of replicated oriC migrates rapidly to the opposite nucleoid border. These oriC copies are retained at both nucleoid borders, remaining at a constant distance from each cell pole. The terminus segment migrates from the nucleoid border to midcell and is retained there until the terminus is duplicated. The origin, terminus and other DNA regions show three migration pattems during active partitioning of daughter chromosomes.
\end{abstract}

[Key Words: Cell division cycle; FISH; mitotic-like apparatus; oriC; positioning; segregation]

Received December 29, 1997; revised version accepted February 4, 1998.

Escherichia coli cells have a 4.6-Mb circular chromosome (Blattner et al. 1997) that is folded and organized in a compact form called the nucleoid. During the cell division cycle, replication of the chromosomal DNA initiates bidirectionally in a specific chromosome region, oriC. The two replication forks meet at the chromosome regi on opposite oriC. In this region, the progress of replication forks traveling clockwise and counter-clockwise is inhibited at specific DNA sequences, ter, in a direction-specific manner (Hill 1996). Thus, this region is replicated at the end of a round of chromosome replication and is called the replication terminus. The replicated chromosomal DNA molecules are physically separated by the processes of decatenation and/or recombination, and then each chromosome is partitioned with high fidelity into daughter cells (for review, see Hiraga 1992; Løbner-Olesen and Kuempel 1992; Rothfield 1994; Wake and Errington 1995). The partitioning mechanism is poorly understood in prokaryotic cells. Recently, bipolar localization of specific chromosome regions during the cell division cycle was reported, and this movement suggested that a mitotic-like apparatus was involved in chromosome partitioning in bacteria (Glaser et al . 1997; Lin et al. 1997; Mohl and Gober 1997; Webb et al. 1997; Wheeler and Shapiro 1997).

Donachie and Begg (1989) and Hiraga et al . (1990) observed that after inhibition of protein synthesis, repli-

${ }^{1}$ Corresponding author.

E-MAIL niki@gpo.kumamoto-u.ac.jp; FAX 96-371-2408. cated chromosomes do not separate from each other but remain together at midcell. When protein synthesis resumed, the chromosomes moved from midcell to cell quarter positions without cell el ongation. This suggested that rapid movement of chromosomes was responsible for chromosome partitioning in bacteria (Hiraga 1990; Hiraga et al. 1990). Bipolar localization of the chromosome segment near oriC was visualized in Bacillus subtilis (Webb et al. 1997) and E. coli (Gordon et al. 1997). Lacl-binding sequences were inserted into the chromosome near oriC, and the green fluorescent protein (GFP) fused to Lacl was detected in living cells. Fluorescent foci of the GFP-Lacl fusion protein bound to the chromosomal site near oriC showed that one copy of the replication origin region moved to the site of new pole formation, near the site of cell division, following replication at or near the cell poles. In addition, bi polar localization of the Spo0J protein was also observed by immunofluorescence microscopy or Spo0J-GFP in B. subtilis (Glaser et al. 1997; Lin et al. 1997). Spo0J binds to a DNA site in the origin-proximal third of the chromosome (Lin et al. 1997) and colocalizes with the oriC region (Lewis and Errington 1997). A spo0J mutant causes production of a significant proportion of anucleate cells and is blocked at the onset of sporulation (Ireton et al. 1994). These results suggested that Spo0] is involved in a mitotic-like apparatus responsible for the migration of the oriC region, and the binding site for SpoOJ is a cisacting site for partitioning, like a eukaryotic centromere. In Caulobacter crescentus, ParB binds to an AT-rich se- 
quence, parS, downstream of the parAB operon, which is located within $80 \mathrm{~kb}$ of the replication origin ( $\mathrm{Mohl}$ and Gober 1997). The ParA and ParB proteins are localized at cell poles in one stage of the cell cycle, and overproduction of ParA and ParB inhibits both cell division and chromosome partitioning. Thus, ParA and ParB may function as components of a mitotic-like apparatus, and the parS site is the only candidate for a centromere that has been sequenced in a bacterial chromosome.

Partition defective mutants that produce anucleate cells upon cell division were isol ated in E. coli (Hiraga et al. 1989). The mukF, mukE, and mukB genes form an operon, and null mutants of each gene show a severe defect in chromosome partitioning and cell viability (Niki et al. 1991; Yamanaka et al. 1996). The mukB gene codes for a filamentous protein of $170 \mathrm{kD}$ whose structure resembles that of motor proteins such as myosin or kinesin (Niki et al. 1992). MukB is presumably responsible for generating motive force during chromosome partitioning. In B. subtilis, the SpollIE protein that localizes at the center of the division septum promotes chromosome segregation into the prespore during sporulation (Wu and Errington 1994, 1997). The origin-proximal third of the chromosome is segregated into the prespore compartment by Spo0J, localized at the cell poles during sporulation (Glaser et al. 1997), and the rest of the chromosome is translocated to the prespore by SpollIE.

In addition to the bipolar behavior of the chromosome origin copies, the $\mathrm{F}$ plasmid al so shows bi pol ar migration of replicated plasmid DNA molecules, which are actively partitioned into daughter cells on cell division (Gordon et al. 1997; Niki and Hiraga 1997). The F plasmid is partitioned to daughter cells with high fidelity owing to two trans-acting genes, sopA and sopB, and a cis-acting site, sopC (Ogura and Hiraga 1983). An F plasmid molecule having the sopABC partitioning system is localized at midcell in newborn cells. The replicated pl asmid molecules migrate in opposite di rections to cell positions one-fourth and three-fourths of the cell length and are tethered at these positions until the cell divides. Therefore, each daughter cell receives at least one $F$ plasmid DNA molecule. P1 plasmid shows the same behavior during the cell division cycle (Gordon et al. 1997). Interestingly, Soj, in an operon with spo0J, and ParA in C. crescentus, bel ong to the ATPase family including the plasmid-encoded F-SopA and P1-ParA proteins, essential for plasmid partitioning. B. subtilis SpoOJ and C. crescentus ParB are members of a family that includes FSopB and P1-ParB. The basic mechanism of the mitoticlike apparatus for chromosome and plasmid migration may be common in various bacteria.

Mitotic-like apparatuses thus seem feasible for chromosome and plasmid partitioning in bacteria. On the other hand, a gradual movement of bulk nucleoids in parallel with cell el ongation has been described (van Helvoort and Woldringh 1994). The distance of nucleoid outer borders and cell poles is constant in living and fixed cells in all stages of the cell division cycle. Therefore, these authors concluded that the partitioning of daughter chromosomes occurs slowly and gradually throughout the cell division cycle and that E. coli does not have a mitotic-like apparatus for rapid chromosome movement during partitioning.

In contrast to the above conclusion, we show here statistical results by FISH indicating that one copy of the duplicated oriC region migrates rapidly al ong the nucleoid from one border to another. We also show a different dynamic migration pattern of the terminus region of the chromosome. By simultaneous use of DN A probes corresponding to different chromosomal regions and labeled with different fluorescent compounds, in situ hybridization revealed cell cycle-dependent nucleoid organization. We propose a model for the positioning of daughter chromosomes.

\section{Results}

Migration of the oriC DNA segment across the nucleoid

Bidirectional chromosome replication is initiated at oriC, which is a minimal 245-bp sequence (Oka et al. 1980) located at $84 \mathrm{~min}$ on the E. coli chromosome. To analyze the intracellular local ization of oriC by FISH, we used two kinds of DNA segments as hybridization probes (Fig. 1). The oriC-gid DNA probe was prepared from a 6.3-kb DNA segment containing the oriC and gid genes. The asn-rbs DN A probe was prepared from about $13 \mathrm{~kb}$ of the oriC-flanking DN A segment containing the asn to rbs genes, but not oriC. There is an $\sim 2$-kb gap between the minimal oriC region and the left border of the asn-rbs DN A segment. Cells of strain CSH50 growing exponentially in minimal glucose medium (doubling time $55 \mathrm{~min}$ ) were fixed and hybridized with either probe (Fig. 2A,B).

One or more apparent fluorescent foci were observed in more than $97 \%$ of cells using the oriC-gid probe. Cells with one, two, three, and four foci were $27 \%, 63 \%, 5.4 \%$, and $4.6 \%$ of total cells having fluorescent foci, respectively. In short cells with a single focus, the focus was local ized at a pole-proximal nucleoid border (Fig. 2A, row a). Two foci in short cells were either closely localized near one nucleoid border (Fig. 2A, row b) or separated from each other (Fig. 2A, rows C-e). In long cells, two foci were localized near the two borders of a nucleoid (Fig. $2 A$, rows $f-h)$. Similar results were obtained with the asn-rbs DN A probe (Fig. 2B), indicating that one copy of the replicated oriC-flanking region, like oriC, also migrated to the opposite border of the nucleoid.

Localization of the oriC DNA segments at a constant distance from the nearest cell pole

To analyze statistically the intracellular distribution of the oriC DNA segment, we measured the distance from the center of each fluorescent focus to the nearest cell pole in 200 cells hybridized with the oriC-gid probe. In cells having a single fluorescent focus, the focus was mainly distributed around the one-fourth position of cell 


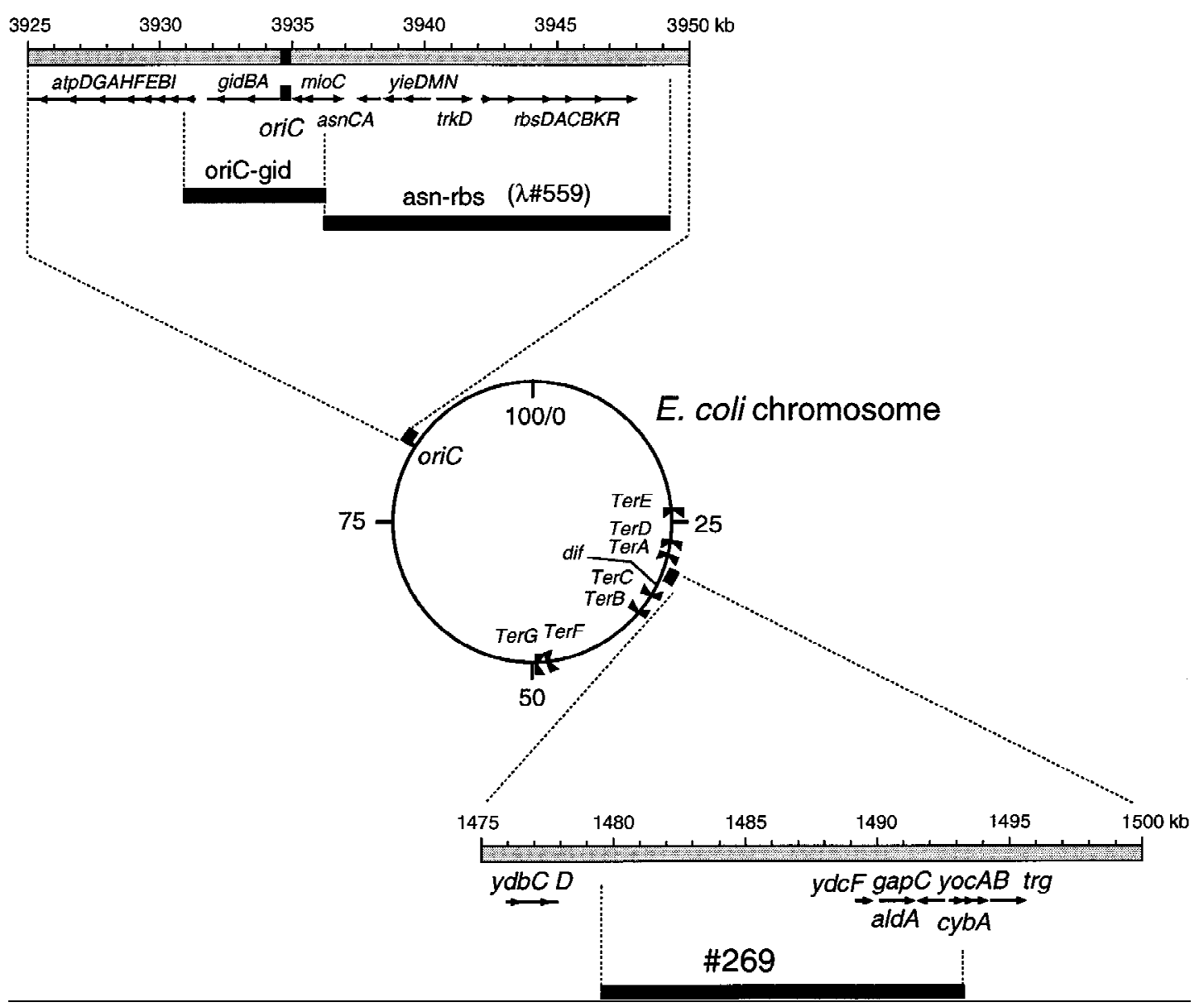

Figure 1. Map of the E. coli chromosome and location of the DNA probes used for FISH. The coordinates of the loci and of Kohara's $\lambda$ phage clones are given in kb according to EcoM ap7 (Berlyn et al. 1996).

length (Fig. 3A,B). It should be noted that the focus of the oriC-gid probe was not localized at the extreme position of the cell pole or midcell. The average cell length of cells with a single focus was $1.45 \pm 0.03 \mu \mathrm{m}$, suggesting that these cells were newborn or in an early stage of the cell division cycle (Fig. 3A; Table 1). The average distance between a focus and the nearest cell pole was $0.40 \pm 0.02 \mu \mathrm{m}$.

In cells with two fluorescent foci, the foci were separated from each other and localized near the cell poles (Fig. 3C). Two foci were al ready separated from each other in short cells of length 1.3-1.5 $\mu \mathrm{m}$, although there were a few cells with two closely located foci. The intracellular distribution of the oriC-gid foci indicated that oriC DNA segments were localized at an approximately constant distance from the nearest cell pole, regardless of cell length. The average distance between a focus and the nearest cell pole was $0.42 \pm 0.02 \mu \mathrm{m}$ ( $T$ able 1). The above results indicate that one of the duplicated oriC copies remained near a nucleoid border, whereas the other mi grated rapidly toward the opposite nucleoid border, where it remained at a constant distance from the nearest cell pole throughout the cell division cycle, until these oriC copies were again replicated.
Migration of a terminus DNA segment from a nucleoid border to midcell

To detect the replication terminus of the E. coli chromosome by the FISH method, we used a fluorescent DNA probe, called the ter probe, which was prepared from the DN A segment located between the 1480- and 1493-kb positions of the chromosome map (Fig. 1). We detected one or two discrete fluorescent foci in CSH50 cells grown exponentially in minimal glucose medium (Fig. 2C). Statistical analysis reveal ed that cells with one or two foci were $74.7 \%$ and $25.3 \%$ of total hybridized cells, respectively; we did not observe cells with three or four foci. In short cells, the terminus DN A was localized near a nucleoid border (Fig. 2C, rows a and b) or at midcell (Fig. 2C, row C). The long cells have a single focus (Fig. $2 \mathrm{C}$, rows $\mathrm{d}$ and e) or two foci located (Fig. $2 \mathrm{C}$, rows $\mathrm{f}-\mathrm{h}$ ) at midcell. The statistical analysis clearly indicated that short cells (1.3-1.5 $\mu \mathrm{m}$ ) have mainly a single focus (Fig. $3 D$ ). The average distance between a focus and the nearest cell pole was $0.32 \pm 0.04 \mu \mathrm{m}$ (Table 2 ). In cells longer than about $1.5 \mu \mathrm{m}$, a single focus and two foci were located in the midcell region (Fig. 3D,F; T able 2). A track of the migrating termi nus DN A segment from the nucleoid 


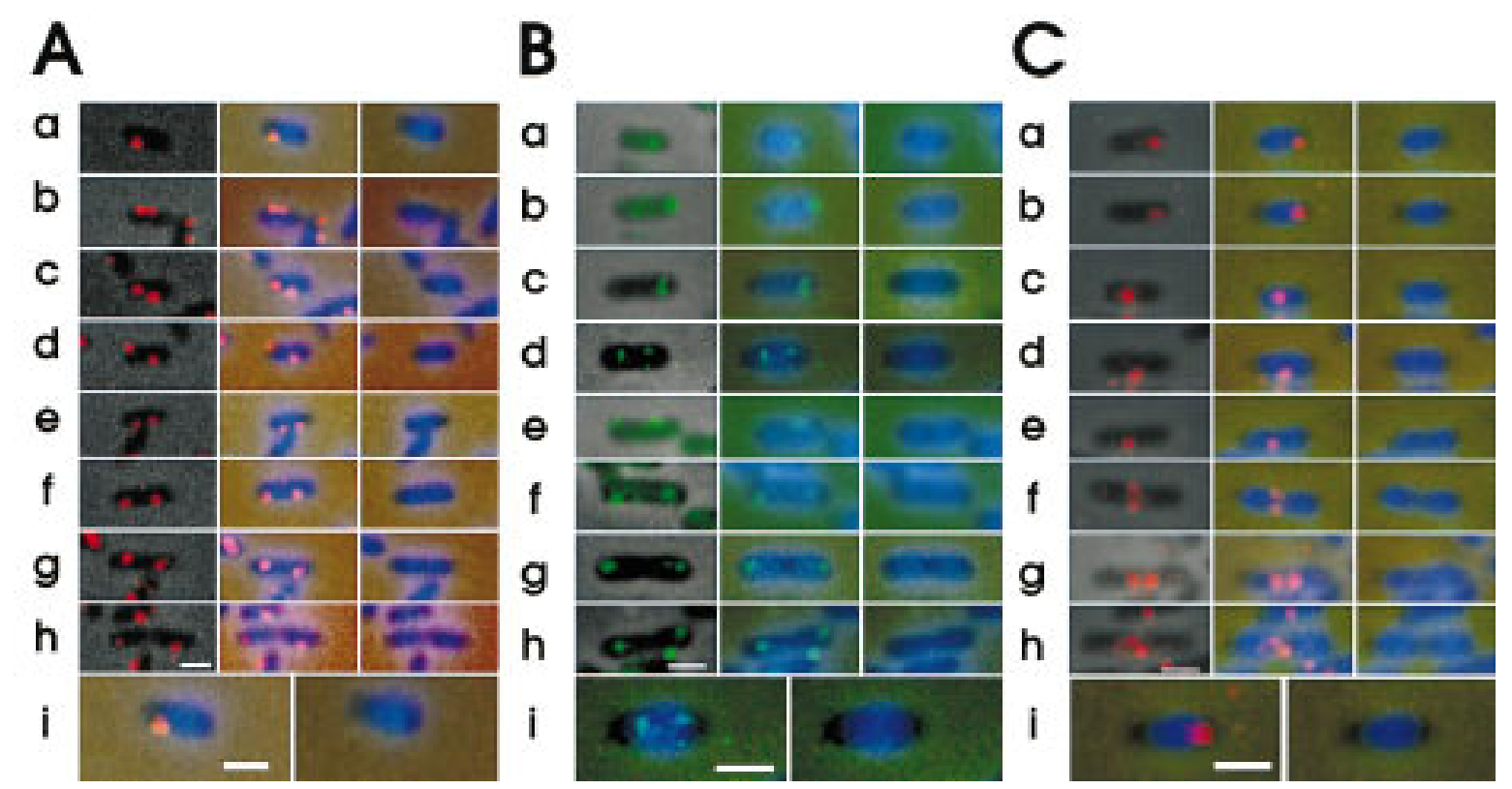

Figure 2. Intracellular localization of replication origin and terminus detected by FISH. Cells of strain CSH50, grown exponentially at $37^{\circ} \mathrm{C}$ in $\mathrm{M} 9$ minimal glucose medium, were fixed. The fixed cells were hybridized with the Cy3-labeled oriC-gid DNA probe (A), the fluorescein-labeled asn-rbs DN A probe (B), and the Cy3-label ed ter DN A probe (C). (Left columns) Combined images of the phase contrast micrograph and fluorescence micrograph for FISH; (middle columns) combined images of the phase contrast micrograph, fluorescence micrograph for FISH and fluorescence micrograph for DAPI; (right columns) combined images of the phase contrast micrograph, and fluorescence micrograph for DAPI. The cells from A row a, B row d, and C row a are shown at higher magnification. Bar, $1 \mu \mathrm{m}$.

border to midcell can be seen in Figure 3D. Thus, these statistical results suggest that the terminus DNA segment was initially localized near a new-pole-proximal nucleoid border and subsequently migrated toward midcell, where it was tethered until the segment was duplicated. The duplicated terminus DNA segments were gradually separated, and a septum was formed between them (Fig. 3E,F).

\section{Bipolarization of the nucleoid in newborn cells}

To investigate the intracell ular local ization of the replication origin and terminus in single cells, we observed simultaneously both the oriC-flanking and terminus DN A segments in cells hybridized with these two probes labeled with different fluorescent compounds: the asnrbs probe with a green fluorescent compound and the ter probe with a red fluorescent compound. Interestingly, the origin-flanking DNA segment was localized at one nucleoid border and the terminus DN A segment at the other in small cells (Fig. 4a). Thus, the nucleoid in newborn cells exhibits polarity, that is, bi polar organization, under growing conditions. In some small cells with two green foci at both nucleoid borders, a red focus was localized at midcell (Fig. 4c-f), suggesting that the terminus DNA segment migrated from the nucleoid border to midcell in an early stage of the cell di vision cycle. On the other hand, copies of the origin-flanking segment were separated from each other and localized at both nucleoid borders (Fig. 4c-f). The terminus segment was dupli cated at midcell, and a septum was formed between these terminus segments (Fig. 4g,h). Therefore, after cell division, a newborn cell had a nucleoid in which the origin-flanking region was localized at the old-pole-proximal nucleoid border and the terminus was localized at the newpole-proximal border.

\section{Arrangement of four OriC DNA segments in a cell}

According to Hel mstetter et al . (1968), chromosome replication should be initiated just before cell division at a doubling time of slightly less than $60 \mathrm{~min}$. We analyzed the number of oriC copies per individual cell in a growing culture (doubling time, $55 \mathrm{~min}$ ) of strain C SH 50 with a flow cytometer. We found that $73 \%$ of the cells had two oriC copies, whereas $37 \%$ had four oriC copies per cell. These results indi cate that chromosome replication was initiated prior to cell division, resulting in four fluorescent ori $C$ foci in the last stage. Indeed, as mentioned above, $4.6 \%$ of the cells had four fluorescent oriC foci and $5.4 \%$ had three. This suggests that the duplicated oriC DN A segments were separated from each other before cell division in a minority of cases, resulting in late stage cells with four oriC copies (Fig. 5). Two oriC copies localized at the two nucleoid borders (Fig. 5a) were duplicated at these positions (Fig. 5b,c). They were arranged along the long cell axis in cells with two nucleoids; the oriC copies were localized at the two borders of each 
A

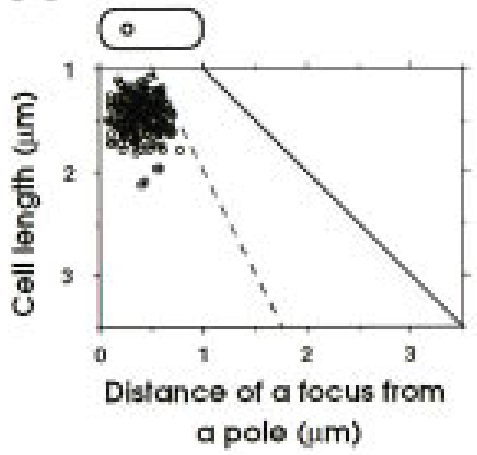

D

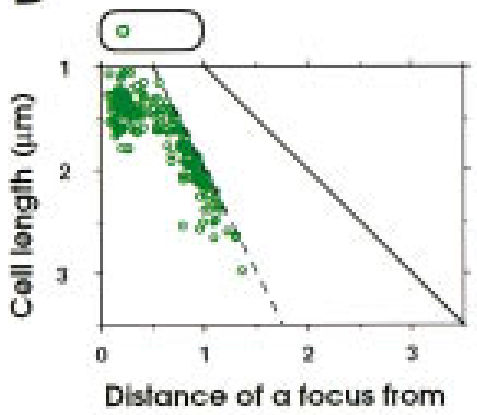

B

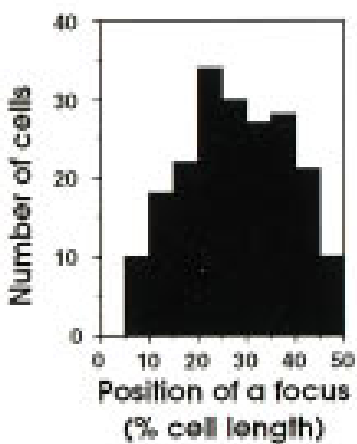

E

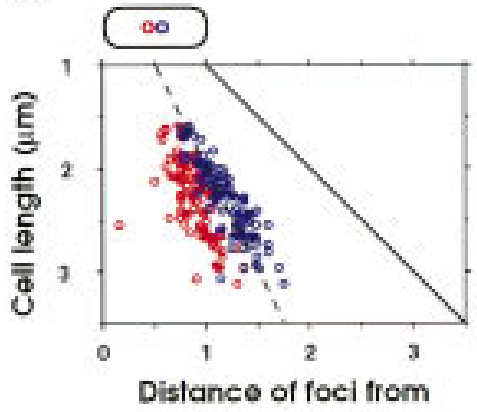

C

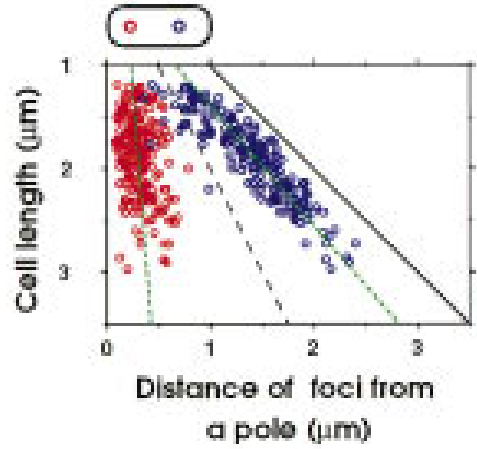

a pole $(\mu \mathrm{m})$

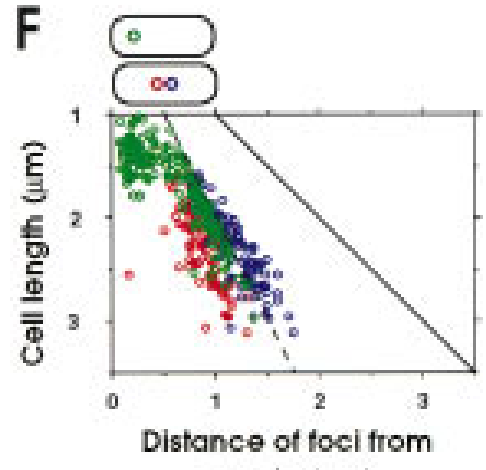

Figure 3. Analysis of intracellular distribution of replication origin and terminus in cells. Fixed cells were hybridized with a Cy3-labeled DNA probe. (A) Cells with a single fluorescent focus of oriC-gid. The distance between the center of the focus and the nearest pole was plotted versus cell length $(n=200)$. (B) Histogram of position of the oriC-gid focus in cells with a single focus. Position of the focus is given as a percent of cell length $(n=200)$. (C) Cells with two fluorescent ori-gid foci. The positions of the foci from a pole are plotted (red and a dark blue circles) versus cell length $(n=200)$. The green broken lines indicate regression lines. (D) Cells with one fluorescent focus of the terminus DNA segment $(n=200)$. (E) Cells with two fluorescent foci of the terminus DNA segment $(n=200)$. ( $F)$ Combination of $D$ and $E$. The black broken line indicates midcell and the black solid line indicates the position of a pole.

nucleoid (Fig. 5d-f). In these cases, a copy of the replicated oriC segments migrated from a cell-pole-proximal border to a midcell-proximal border of a nucleoid. This observation is consistent with the migration of oriC DNA segments in living cells observed with the LaclGFP system (Gordon et al. 1997).

\section{Discussion}

In this paper we have shown the intracellular localization of specific chromosomal DN A segments during the cell division cycle (Fig. 6A). Our major observations and conclusion are the following: (1) In newborn cells, an

Table 1. Intracellular localization of fluorescent oriC foci

\begin{tabular}{|c|c|c|c|c|c|c|c|}
\hline \multirow{2}{*}{$\begin{array}{l}\text { Type } \\
\text { of cells }\end{array}$} & \multirow{2}{*}{$\begin{array}{l}\text { Classification of } \\
\text { cell length }(\mu \mathrm{m})\end{array}$} & \multirow{2}{*}{$\begin{array}{l}\text { A verage cell } \\
\text { length }(\mu \mathrm{m}) \\
(\mathrm{L})\end{array}$} & \multirow{2}{*}{$\begin{array}{l}\text { A verage position } \\
\text { of one-quarter }(\mu \mathrm{m}) \\
(\mathrm{L}) \times 1 / 4\end{array}$} & \multicolumn{3}{|c|}{$\begin{array}{l}\text { Distance of a focus } \\
\text { from a pole }(\mu \mathrm{m})\end{array}$} & \multirow{2}{*}{$\begin{array}{l}\text { Number of } \\
\text { sample cells }\end{array}$} \\
\hline & & & & left & right & average & \\
\hline 1 & $\begin{array}{l}1.0 \leqslant \text { C.L. }<1.5 \\
1.0 \leqslant \text { C.L. }<2.0\end{array}$ & $\begin{array}{l}1.35 \pm 0.02 \\
1.63 \pm 0.02\end{array}$ & $\begin{array}{l}0.34 \\
0.41\end{array}$ & $\begin{array}{l}0.39 \pm 0.03 \\
0.42 \pm 0.04\end{array}$ & & & $\begin{array}{r}126 \\
72\end{array}$ \\
\hline \multirow[t]{2}{*}{2} & $\begin{array}{c}\text { total cells } \\
1.0 \leqslant \text { C.L. }<1.5 \\
1.5 \leqslant \text { C.L. }<2.0 \\
2.0 \leqslant \text { C.L. }<2.5 \\
2.5 \leqslant \text { C.L. }<3.0\end{array}$ & $\begin{array}{l}1.45 \pm 0.03 \\
1.35 \pm 0.03 \\
1.75 \pm 0.02 \\
2.23 \pm 0.02 \\
2.71 \pm 0.06\end{array}$ & $\begin{array}{l}0.36 \\
0.34 \\
0.43 \\
0.56 \\
0.68\end{array}$ & $\begin{array}{l}0.40 \pm 0.02 \\
0.28 \pm 0.04 \\
0.30 \pm 0.03 \\
0.37 \pm 0.04 \\
0.44 \pm 0.10\end{array}$ & $\begin{array}{l}0.47 \pm 0.06 \\
0.47 \pm 0.04 \\
0.55 \pm 0.04 \\
0.60 \pm 0.09\end{array}$ & $\begin{array}{l}0.38 \pm 0.01 \\
0.39 \pm 0.03 \\
0.46 \pm 0.03 \\
0.52 \pm 0.07\end{array}$ & $\begin{array}{r}198 \\
36 \\
86 \\
65 \\
13\end{array}$ \\
\hline & total cells & $1.90 \pm 0.06$ & 0.48 & $0.33 \pm 0.02$ & $0.51 \pm 0.03$ & $0.42 \pm 0.02$ & 200 \\
\hline
\end{tabular}

aType 1 of cells had one fluorescent oriC focus; type 2 of cells had two fluorescent oriC foci. 
Table 2. Intracellular localization of a single fluorescent focus of the terminus region

\begin{tabular}{|c|c|c|c|c|}
\hline $\begin{array}{l}\text { Classification of } \\
\text { cell length }(\mu \mathrm{g})\end{array}$ & $\begin{array}{l}\text { A verage cell } \\
\text { length }(\mu \mathrm{m}) \\
(\mathrm{L})\end{array}$ & $\begin{array}{l}\text { Average position } \\
\text { of mid-cell }(\mu \mathrm{m}) \\
(\mathrm{L}) \times 1 / 2\end{array}$ & $\begin{array}{l}\text { Distance of a focus } \\
\text { from a pole }(\mu \mathrm{m})\end{array}$ & $\begin{array}{l}\text { N umber of } \\
\text { sample cells }\end{array}$ \\
\hline $1.0 \leqslant$ C.L. $<1.5$ & $1.34 \pm 0.03$ & 0.67 & $0.32 \pm 0.04$ & 77 \\
\hline $1.5 \leqslant$ C.L. $<2.0$ & $1.73 \pm 0.02$ & 0.87 & $0.66 \pm 0.06$ & 79 \\
\hline $2.0 \leqslant$ C.L. $<2.5$ & $2.18 \pm 0.02$ & 1.09 & $0.99 \pm 0.03$ & 37 \\
\hline $2.5 \leqslant$ C.L. $<3.0$ & $2.70 \pm 0.13$ & 1.35 & $1.15 \pm 0.20$ & 7 \\
\hline Total cells & $1.69 \pm 0.05$ & 0.85 & $0.60 \pm 0.05$ & 200 \\
\hline
\end{tabular}

oriC DNA segment is localized at an old-pole-proximal border of a nucleoid, but not at the cell pole; (2) one copy of the duplicated oriC DNA segments remains at the old-pole-proximal border, whereas the other copy migrates along the nucleoid to the opposite nucleoid border; (3) the distance between an oriC DN A segment and the nearest cell pole is constant throughout the cell division cycle; (4) the oriC-flanking region hybridized with the asn-rbs DNA probe shows a migration pattern simiIar to that of the oriC region; (5) the terminus DN A segment is localized at the new-pole-proximal nucleoid border in newborn cells; (6) the terminus DNA segment migrated from the nucleoid border to midcell in an early stage of the cell division cycle; (7) migration of the oriC and terminus DNA segments was not coupled to cell elongation; and (8) duplicated terminus DNA regions were separated from each other at the last stage of chromosome separation. These resul ts indicate the existence of a mitotic-like apparatus. The distance between the nucleoid outer border and cell pole remains constant during all stages of the cell division cycle (van Helvoort and Woldringh 1994). The bulk repl icated nucleoids thus seems to migrate gradually during cell el ongation. However, the dynamic migration of the replication origin and terminus, which is not coupled to envel ope el ongation, is involved in the nucleoid movement for positioning of daughter chromosomes, as shown in Results.

E. coli chromosomal DNA is folded into about 50 loops per chromosome (Pettijohn and Hecht 1974). The oriC and terminus DNA segments may be located in loops of the folded chromosome rather than in the core structure. The migration of oriC DNA segment in an early stage of the cell division cycle is important for chromosome partitioning as described in a model (Fig. $6 \mathrm{~B})$. However, the oriC DN A sequence itself presumably does not have a function for the migration of oriC DNA segments along the nucleoid, since oriC plasmids are unstably maintained, although oriC plasmids carrying

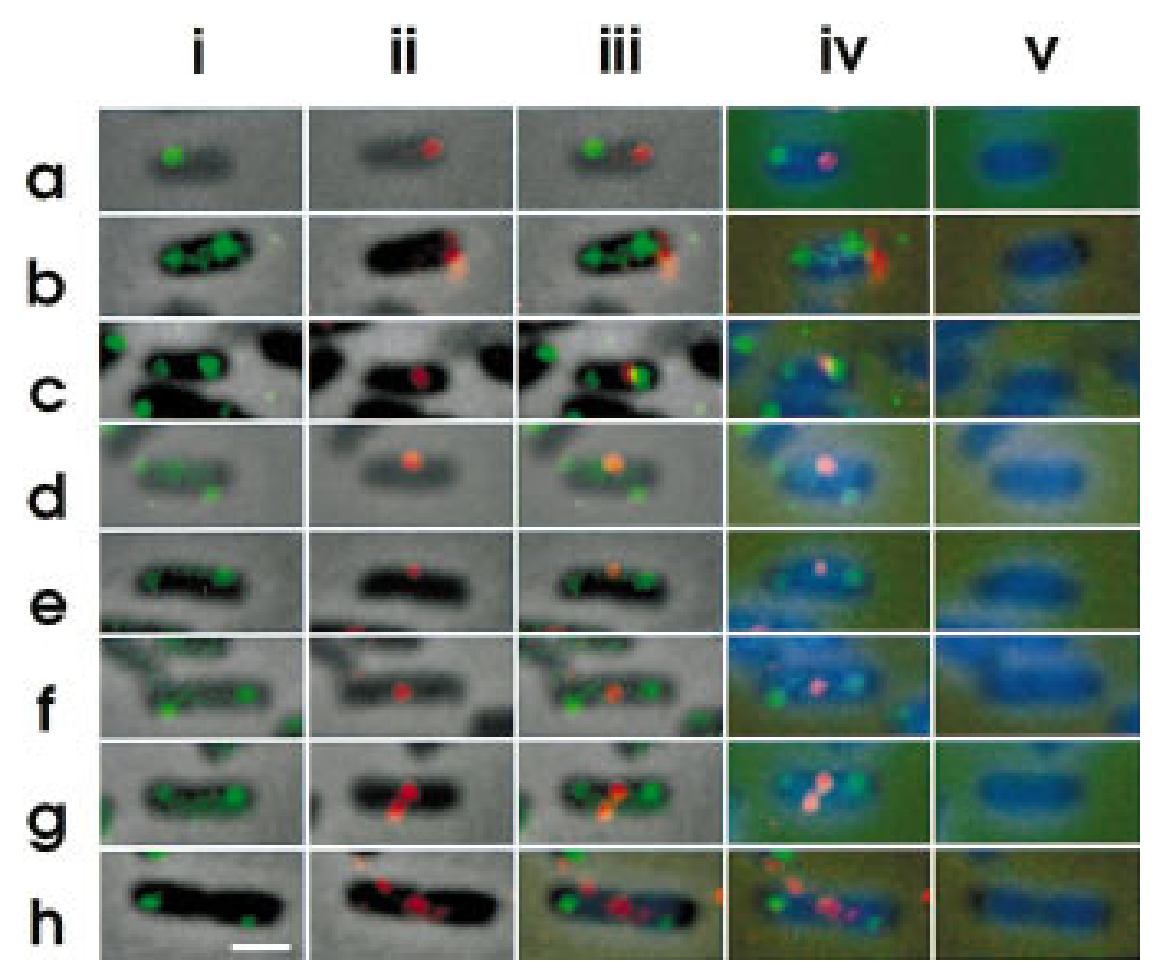

Figure4. Intracellular localization of replication origin and terminus. Cells were hybridized simultaneously with the fluorescein-labeled asn-rbs DNA probe and the Cy3-labeled ter DNA probe. (i) asnrbs; (ii) ter; (iii) asn-rbs and ter; (iv) asnrbs, ter, and DAPI. (v) DAPI; Bar, $1 \mu \mathrm{m}$. 


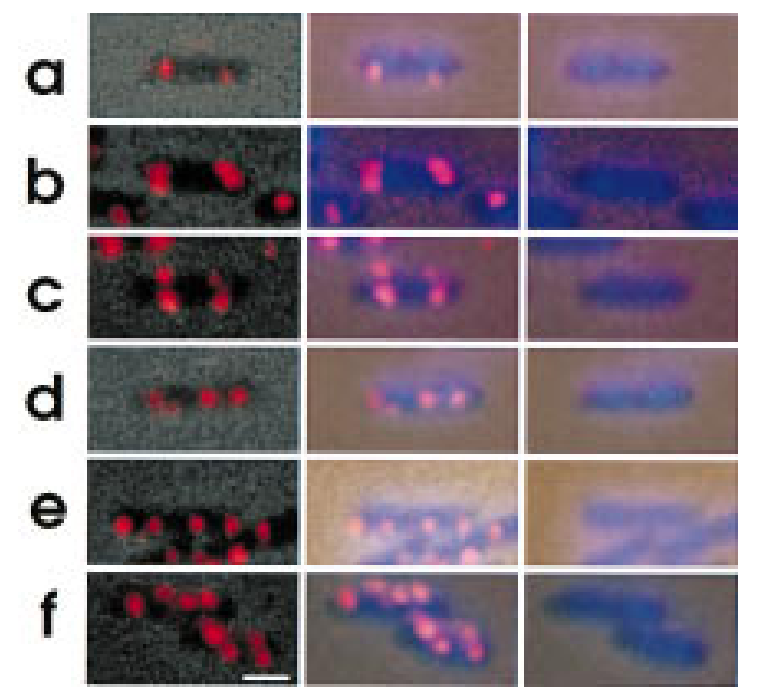

Figure 5. Intracellular localization of replication origin. Cells were grown, fixed and hybridized with the oriC-gid DN A probe as described in the legend to Fig. 2. (Left column) Combined images of the phase contrast micrograph and fluorescence micrograph of the same field; (middle column) combined images of fluorescence micrograph and phase contrast-DAPI micrograph; (right column) images of phase contrast-DAPI. Bar, $1 \mu \mathrm{m}$.

the sopA BC segment of $\mathrm{F}$ plasmid are stably maintained (Ogura and Hiraga 1983; Hiraga 1992). A putative cisacting specific DN A sequence(s) responsible for ori C migration may be located in the oriC-containingloop. After migration, the cis-acting sequence(s) may be attached to a peripheral site of the cell membrane, with the result that oriC is localized at a constant distance from the nearest cell pole. In C. cresentus, a cis-acting parS site for chromosome partitioning, located $\sim 80 \mathrm{~kb}$ from the replication origin, may act as a centromere (Mohl and Gober 1997). In B. subtilis, the binding sites of Spo0], which is responsible for chromosome partitioning, are localized in the origin-proximal third of the chromosome. It is likely that bacterial cells have a cis-acting site(s) like a eukaryotic centromere near the replication origin. A DN A loop containing the terminus region may have another cis-acting DNA sequence(s) that ensures the specific migration pattern of the terminus region.

There are differences between the number of oriC copies per cell and the number of fluorescent oriC-gid foci. The results indicate that the ori $C$ segment is duplicated before cell division under our growth conditions, and these oriC copies are located close to one another in newborn cells and in early stages, so that they are observed as a single fluorescent focus in $27 \%$ of the cells. The duplicated oriC copies seem to be close to each other for approximately the first $15 \mathrm{~min}$ of the $55 \mathrm{~min}$ doubling time, enough for duplication of the originproximal third of the chromosome. For the dynamic migration of oriC and its flanking regions, the putative centromere region(s) must be duplicated, specific proteins must bind to the duplicated regions, and an unidentified mitotic-like apparatus must be activated.
A growing cell has three types of sites related to cell division. The first is the next cell division site at midcell. The second is future cell division sites at positions onefourth and three-fourths of the cell length. The third is the old cell division sites at both cell poles. The old cell division sites have potential for septum formation, but this is suppressed by the minCD gene products (de Boer et al. 1989). It is thought that the specialized structures that organize cell division, called periseptal annuli, exist at these sites (de Boer et al. 1990). Cell quarter sites are important for the sopABC partitioning system of mini-F

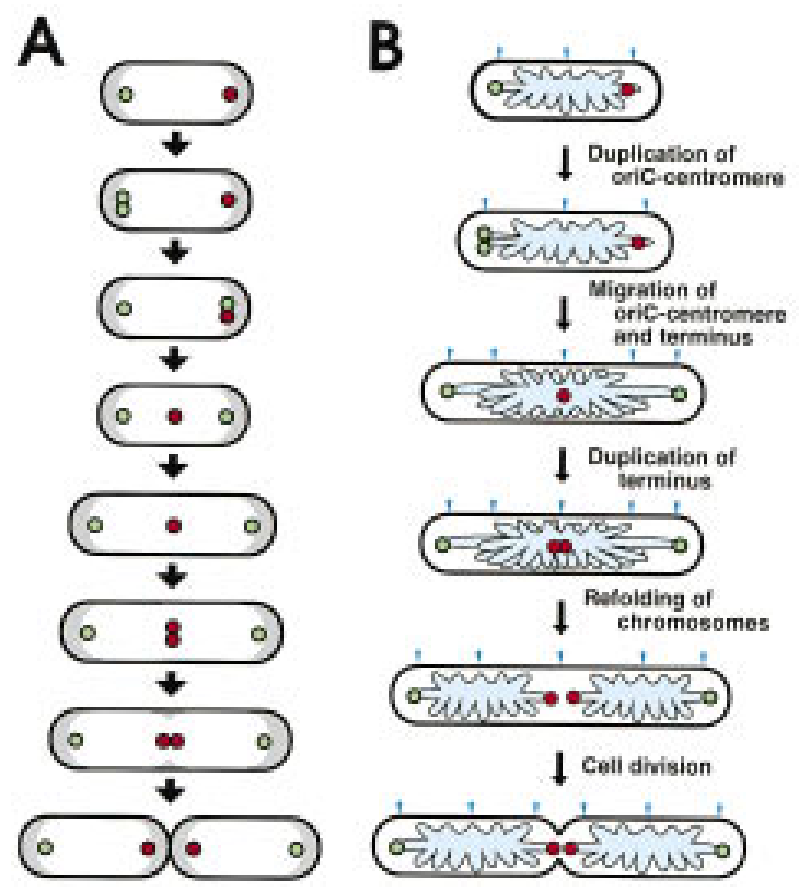

Figure 6. Schema of intracellular localization of replication origin and terminus during cell division cycle and a model of chromosome partioning in E. coli. (A) In cells growing with a 60 -min doubling time, a replicated origin DN A segment (green circle) on the chromosome is local ized near a nucleoid border in newborn cells. One copy of the replicated origin segment remains at the same position, whereas the other migrates to the opposite nucleoid border, where the replication terminus (red circle) is localized. Subsequently, the replication terminus migrates to midcell. The distance between an origin DN A segment and the nearest cell pole is constant during the cell division cycle, despite cell el ongation. One round of chromosome replication is completed, and the terminus segment is duplicated at midcell. A septum is formed at midcell, resulting in newborn cells that have a replication terminus localized at the nucleoid border near a pole newly created by cell division. On the other hand, the replication origin is localized at the other nucleoid border, near the old pole. White and gray regions indicate nucleoid and cytosol spaces, respectively. (B) A model of partitioning of daughter chromosomes. A putative cis-acting sequence for migration, oriC-centromere, is located in a loop containing oriC. The specific migration patterns of oriC-centromere (green circle) and terminus (red circle) are shown in cells during the cell division cycle. The pale blue region and arrow head indicate the folded chromosome and the cell division site, respectively. 
plasmid. Mini-F plasmid DN A is localized at midcell in newborn cells. After replication, duplicated molecules migrate in opposite directions from midcell to the cell quarter positions and are tethered there until the cell divides (Niki and Hiraga 1997). The DN A-protein complexes of sopC DN A, SopA and SopB (Hirano et al. 1998) may play an important role for migration and tethering at the cell quarter positions. M ini-P1 plasmid molecules migrate similarly from midcell to cell quarter positions (Gordon et al. 1997). Furthermore, using immunofluorescence microscopy, we have found that SeqA fluorescent foci are duplicated and migrate from midcell to the cell quarters in a cell cycle-dependent manner (Hiraga et al. 1998). It is thought that SeqA is involved in replication initiation by the sequestration of oriC and/or modulation of the cellular level of DNA activity (von Feiesleben et al. 1994; Lu et al. 1994; Slater et al. 1995; Garwood and Kohiyama 1996). The SeqA foci were not formed at oriC but in another chromosomal region. The intracellular local ization of SeqA-associated DN A-protein complexes was abnormal in mukB null mutants. The SeqA-associated DN A-protein complex may play an important role, direct or indirect, in the migration and tethering of bulk daughter chromosomes at cell quarter sites (Hiraga et al. 1998). Putative centromere sites in a chromosomal loop containing oriC are presumably tethered at the old cell division site in newborn cells. The cell division sites must be closely related to chromosome and plasmid migration and partitioning.

In summary, we present a model of chromosome partitioning in E. coli (Fig. 6B) based on three different migration patterns of chromosomal regions during the cell division cycle; (1) migration al ong a nucl eoid of a putative centromere located near oriC; and (2) migration of a cis-acting sequence(s) in the terminus region from a nucleoid border to midcell. The migration al ong a nucleoid of one copy of duplicated DN A regions containing a putative centromere and oriC determines the direction of positioning of daughter chromosomes. Subsequently, the termi nus regi on migrates to midcell, that is, between the two oriC regions. Newly synthesized DNA strands accumulate in cells during the progression of replication forks. After the termination of chromosomal replication, SeqA-associated DNA-protein complexes migrate to the cell quarter sites and presumably act as refol ding centers of the daughter chromosomes, resulting in two separated nucleoids (Hiraga et al. 1998). Duplicated terminus regions are pulled in opposite directions and finally are separated into two nucleoids during migration and/or refolding of bulk daughter chromosomes at the cell quarter positions.

To resolve dimeric daughter chromosomes to monomers before cell division, the terminus regi on has a hyperrecombination site for the XerCE-dependent site-specific recombination and a terminal recombination regi on (TRZ) (Hill 1996). Interestingly, both dif, which is the XerCE recognition site, and TRZ function only when they are ocated at the proper position in the chromosomal terminus (Louarn et al. 1994; Cornet et al. 1996; Kuempel et al. 1996). The dif locus might be positioned in a TRZ loop of the folded chromosome, and TRZ regions are final ly separated in the process of chromosome partitioning (Louarn et al. 1994). The dif resolution specificity might be dependent on the chromosomal location that is finally pulled apart (Baker 1991). Our observation of the migration pattern of the terminus is consistent with this model of TRZ and dif.

\section{Materials and methods}

Bacteria, plasmids, and culture conditions

An E. coli K-12 derivative, CSH50 [ara ( $\Delta$ lac-pro) strA thi] (Miller 1972), was used. Cells were cultivated at $37^{\circ} \mathrm{C}$ in $\mathrm{M} 9$ medium (Miller 1972) supplemented with glucose $(0.5 \%)$, proline $(50 \mu \mathrm{g} / \mathrm{ml})$, and thiamine $(2 \mu \mathrm{g} / \mathrm{ml})$ for FISH. Under growing conditions, the doubling time of CSH50 cells was 55 min.

Fluorescent probes for in situ hybridization

To detect the replication origin DNA segment of the E. coli chromosome in fixed cells by in situ hybridization, we used the oriC-gid probe DNA segment containing mioC, oriC, gidAB, and a part of atpl, which was amplified from CSH 50 chromosomal DNA by PCR. The primer sequences for the oriC-gid DNA segment were 5'-TCAGGATAAATACGCCCAGTGCCATAGACAGCG-3' and 5'-AGCTCTGACGGGGTGCTCCAGTCATCATAATCC- 3 '. We also used Kohara's $\lambda$ phage clones; no. 559 for the origin-flanking region and no. 269 for the terminus DN A segment (Kohara et al. 1987). The cloned chromosomal DNA segments of these $\lambda$ clones were amplified by PCR according to Oshima et al. (1996). The PCR products (1 $\mu \mathrm{g})$ were labeled with Cy3-dCTP (Amersham) or Fluorescein-11dUTP (Amersham) by use of a random-primed DN A labeling kit (Boehringer). After removing nonincorporated substrates by ethanol precipitation, the labeled probe DNA was resolved in hybridization buffer ( $50 \%$ formamide, $2 \times$ SSC, $100 \mu \mathrm{g} / \mathrm{ml}$ salmon sperm DN A). The probe DN A in the hybridization mixture was sonicated for $15 \mathrm{sec}$ and denatured by heating to $80^{\circ} \mathrm{C}$ for $10 \mathrm{~min}$ before hybridization.

FISH and image analysis

To fix cells, an equal volume of fixation solution [methanol:acetic acid $(3: 1)$ ] was added directly to a bacterial culture growing exponentially in $\mathrm{M} 9$ glucose medium at $37^{\circ} \mathrm{C}$. The FISH was carried out according to the procedure described previously (N iki and Hiraga 1997). All images were recorded with a cooled CCD camera, C5810-01 (Hamamatsu, Japan), by use of a phase contrast and fluorescence microscopy system ( $\mathrm{N}$ ikon). The images were transferred directly to a Power Macintosh and processed by use of A dobe Photoshop 4.0-J software. The image was printed on a Pictrography 3000 (Fuji).

Measuring number of oriC copies in individual cells by flow cytometry

The number of oric copies in individual cells was determined by flow cytometory (Bio-Rad) according to the method described previously (Løbner-Olesen et al. 1989).

\section{Acknowledgments}

We thank R. D'Ari for critically reading the manuscript and comments. This work was supported by Grant-in-Aid for Sci- 
entific Research on Priority A reas and a grant for International Scientific Research Programs for Joint Research from the Ministry of Education, Science, Sports, and Culture of Japan, and by a grant from the Human Frontier Science Program (contact no. RG-386/95M)

The publication costs of this article were defrayed in part by payment of page charges. This article must therefore be hereby marked "advertisement" in accordance with 18 USC section 1734 solely to indicate this fact.

\section{References}

Baker, T. 1991. . . . and then there were two. Nature 352: 794795.

Berlyn, M.K.B., B. Low, and K.E. Rudd. 1996. Linkage map of E. coli K-12. In Escherichia coli and Salmonella typhimurium: Cellular and molecular biology (ed. F.C. N eidhardt, R. Curtiss III, J.L. Ingraham, E.C.C. Lin, K.B. Low, B. Magasanik, W.S. Reznikoff, M. Riley, M. Schaechter, and E.D. Umbarger), pp. 1715-1902. American Society for Microbiology, Washington, DC.

Blattner, F.R., G. Plunkett III, C.A. Bloch, N.T. Perna, V. Burland, M. Riley, J. Collado-Vides, J.D. Glasner, C.K. Rode, G.F. Mayhew, J. Gregor, N.W. Davis, H.A. Kirkpatrick, M .A. Goeden, D.J. Rose, B. Mau, and Y. Shao. 1997. The complete genome sequence of Escherichia coli K-12. Science 277: 1453-1474.

Cornet, F., J. Louarn, J. Patte, and J.M. Louarn. 1996. Restriction of the activity of the recombination site dif to a small zone of the Escherichia coli chromosome. Genes \& Dev. 10: 1152-1161.

de Boer, P.A.J., R.E. Crossley, and L.I. Rothfield. 1989. A division inhibitor and a topological specificity factor coded for by the minicell locus determine proper placement of the division septum in E. coli. Cell 56: 641-649.

de Boer, P.A.J., W.R. Cook, and L.I. Rothfield. 1990. Bacterial cell division. Annu. Rev. Genet. 24: 249-274.

Donachie, W.D. and K.J. Begg. 1989. Chromosome partition in Escherichia coli requires postreplication protein synthesis. J. Bacteriol. 171: 5405-5409.

Garwood, J. and M. Kohiyama. 1996. A novel cytoplasmic hemimethylated oriC binding activity. J. Biol. Chem. 271: 74047411.

Glaser, P., M.E. Sharpe, B. Raether, M. Perego, K. Ohlsen, and J. Errington. 1997. Dynamic, mitotic-like behavior of a bacterial protein required for accurate chromosome partitioning Genes \& Dev. 9: 1160-1168.

Gordon, G.S., D. Sitnikov, C.D. Webb, A. Teleman, A. Straight, R. Losick, A.W. Murray, and A. Wright. 1997. Chromosome and low copy plasmid segregation in E. coli: Visual evidence for distinct mechanisms. Cell 90: 1113-1121.

Helmstetter, C.E., S. Cooper, O. Pierucci, and L. Revelas. 1968 The bacterial life sequence. Cold Spring Harbor Symp. Quant. Biol. 33: 809-822.

Hill, T.M. 1996. Features of the chromosomal terminus region. In Escherichia coli and Salmonella typhimurium: Cellular and molecular biology (ed. F.C. N eidhardt, R. Curtiss III, J.L. Ingraham, E.C.C. Lin, K.B. Low, B. Magasanik, W.S. Reznikoff, M. Riley, M. Schaechter, and E.D. U mbarger), pp. 16021614. American Society for Microbiology, Washington, DC.

Hiraga, S. 1990. Partitioning of nucleoids. Res. Microbiol. 141: $50-56$

- - 1992. Chromosome and plasmid partition in Escherichia coli. Annu. Rev. Biochem. 61: 283-306.

Hiraga, S., H. N iki, T. Ogura, C. Ichinose, H. M ori, B. Ezaki, and
A. Jaffé. 1989. Chromosome partitioning in Escherichia coli: Novel mutants producing anucleate cells. J. Bacteriol. 171: 1496-1505.

Hiraga, S., T. Ogura, H. Niki, C. Ichinose, and H. Mori. 1990. Positioning of replicated chromosomes in Escherichia coli. J. Bacteriol. 172: 31-39.

Hiraga, S., C. Ichinose, H. Niki, and M. Yamazoe. 1998. Cell cycle-dependent duplication and bidirectional migration of SeqA-associated DNA-protein complexes in E. coli. Mol. Cell 1: 381-387.

Hirano, M., H. M ori, T. Onogi, M. Yamazoe, H. Niki, T. Ogura, and S. Hiraga. 1998. Autoregulation of the partition genes of the mini-F plasmid and the intracellular localization of their products in Escherichia coli. Mol. Gen. \& Genet. 257: 392403.

Ireton, K., N.W.I. Gunther, and A.D. Grossman. 1994. spo0] is required for normal chromosome segregation as well as the initiation of sporulation in Bacillus subtilis. J. Bacteriol. 176: 5320-5329.

Kohara, Y., K. Akiyama, and K. Isono. 1987. The physical map of the whole E. coli chromosome: Application of a new strategy for rapid analysis and sorting of a large genomic library. Cell 50: 495-508.

Kuempel, P., A. Hogaard, M. N ielsen, O. Nagappan, and M. Tecklenburg. 1996. Use of a transposon (Tndif) to obtain suppressing and nonsuppressing insertions of the dif resolvase site of Escherichia coli. Genes \& Dev. 10: 1162-1171.

Lewis, P.J. and J. Errington. 1997. Direct evidence for active segregation of oriC regions of the Bacillus subtilis chromosome and co-localization with the Spo0J partitioning protein. Mol. Microbiol. 25: 945-954.

Lin, D.C.-H., P.A. Levin, and A.D. Grossman. 1997. Bipolar localization of a chromosome partition protein in Bacillus subtilis. Proc. Natl. Acad. Sci. 94: 4721-4726.

Løbner-Olesen, A. and P.L. Kuempel. 1992. Chromosome partitioning in Escherichia coli. J. Bacteriol. 174: 7883-7889.

Løbner-Olesen, A., K. Skarstad, F.G. Hansen, M.K. von, and E. Boye. 1989. The DnaA protein determines the initiation mass of Escherichia coli K-12. Cell 57: 881-889.

Louarn, J., F. Cornet, V. Francois, J. Patte, and J.M. Louarn. 1994. Hyperrecombination in the terminus region of the Esche richia coli chromosome: Possible relation to nucleoid organization. J. Bacteriol. 176: 7524-7531.

Lu, M., J.L. Campbell, E. Boye, and N. Kleckner. 1994. SeqA: A negative modulator of replication initiation in E. coli. Cell 77: 413-426.

Miller, J.H. 1972. Experiments in molecular genetics. Cold Spring Harbor Laboratory, Cold Spring Harbor, NY.

Mohl, D.A. and J.W. Gober. 1997. Cell cycle-dependent polar localization of chromosome partitioning proteins in Caulobacter crescentus. Cell 88: 675-684.

$\mathrm{Niki}, \mathrm{H}$. and S. Hiraga. 1997. Subcellular distribution of actively partitioning $\mathrm{F}$ plasmid during the cell division cycle in $\mathrm{E}$. coli. Cell 90: 951-957.

Niki, H., A. Jaffé, R. Imamura, T. Ogura, and S. Hiraga. 1991. The new gene mukB codes for a $177 \mathrm{kd}$ protein with coiledcoil domains involved in chromosome partitioning of E.coli. EMBO J. 10: 183-193.

Niki, H., R. Imamura, M. Kitaoka, K. Yamanaka, T. Ogura, and S. Hiraga. 1992. E. coli MukB protein involved in chromosome partition forms a homodimer with a rod-and-hinge structure having DNA binding and ATP/GTP binding activities. EMBO J. 11: 5101-5109.

Ogura, T. and S. Hiraga. 1983. Partition mechanism of F plasmid: Two plasmid gene-encoded products and a cis-acting 
region are involved in partition. Cell 32: 351-360.

Oka, A., K. Sugimoto, M. Takanami, and Y. Hirota. 1980. Replication origin of the Escherichia coli $\mathrm{K}-12$ chromosome: The size and structure of the minimum DNA segment carrying the information for autonomous replication. Mol. \& Gen. Genet. 178: 9-20.

Oshima, T., H. Aiba, T. Baba, K. Fujita, K. Hayashi, A. Honjo, K. Ikemoto, T. Inada, T. Itoh, M. Kaji hara et al. 1996. A 718-kb DNA sequence of the Escherichia coli K-12 genome corresponding to the $12.7-28.0 \mathrm{~min}$ region on the linkage map. DNA Res. 3: 137-155.

Pettijohn, D.E. and R. Hecht. 1974. RNA molecules bound to the folded bacterial genome stabilize DNA folds and segregate domains of supercoiling. Cold Spring Harbor Symp. Quant. Biol. 38: 31-41.

Rothfield, L.I. 1994. Bacterial chromosome segregation. Cell 77: 963-966.

Slater, S., S. Wold, M. Lu, E. Boye, K. Skarstad, and N. Kleckner. 1995. E. coli SeqA protein binds oriC in two different methyl-modulated reactions appropriate to its roles in DN A replication initiation and origin sequestration. Cell 82: 927936.

van Helvoort, J.M .L.M . and C.L. Woldringh. 1994. N ucleoid partitioning in Escherichia coli during steady-state growth and upon recovery from chloramphenicol treatment. Mol. Microbiol. 13: 577-583.

von Freiesl eben, U., K.V. Rasmussen, and M. Schaechter. 1994. SeqA limits DnaA activity in replication from oriC in Escherichia coli. Mol. Microbiol. 14: 763-772.

Wake, R.G. and J. Errington. 1995. Chromosome partitioning in bacteria. Annu. Rev. Genet. 29: 41-67.

Webb, C.D., A. Teleman, S. Gordon, A. Straight, A. Belmont, D.C.-H. Lin, A.D. Grossman, A. Wright, and R. Losick. 1997. Bipolar localization of the replication origin regions of chromosomes in vegetative and sporulating cells of $B$. subtilis. Cell 88: 667-674.

Wheeler, R.T. and L. Shapiro. 1997. Bacterial chromosome segregation: Is there a mitotic apparatus? Cell 88: 577-579.

Wu, L.J. and J. Errington. 1994. Bacillus subtilis SpollIE protein required for DNA segregation during asymmetric cell division. Science 264: 572-575.

- - . 1997. Septal localization of the SpollIE chromosome partitioning protein in Bacillus subtilis. EMBO J. 16: 21612169.

Yamanaka, K., T. Ogura, H. Niki, and S. Hiraga. 1996. Identification of two new genes, mukE and mukF, involved in chromosome partitioning in Escherichia coli. Mol. \& Gen. Genet. 250: 241-251. 